\title{
BENTUK PERKAWINAN MATRIARKI PADA MASYARAKAT HINDU BALI DITINJAU DARI PERSPEKTIF HUKUM ADAT DAN KESETARAAN GENDER
}

\author{
Ni Ketut Sari Adnyani \\ UNDIKSHA, Singaraja
}

e-mail: sariadnyani@yahoo.co.id

\begin{abstract}
Abstrak
Secara umum penelitian ini bertujuan untuk mengembangkan model hukum perkawinan berorientasi gender berbasis desa adat Hindu Bali. Penelitian ini akan dilakukan selama 3 tahun, yaitu dari tahun 2015 sampai dengan tahun 2016. Luaran penelitian selama tiga tahun dapat dijabarkan sebagai berikut: (1) luaran tahun I (2015) terdiri adalah artikel ilmiah di jurnal terakreditasi, dan draft buku ajar hukum waris pengaruh dari perkawinan berorientasi gender berbasis desa adat Hindu Bali. (2) luaran tahun II (2016) terdiri adalah artikel ilmiah di jurnal nasional terakreditasi, dan buku ajar terkait dengan hukum waris pengaruh dari perkawinan berorientasi gender berbasis desa adat Hindu Bali, dan artikel ilmiah di jurnal internasional. Hasil penelitian bentuk perkawinan matriarki di beberapa daerah di provinsi Bali seperti Buleleng, Tabanan, Gianyar, telah dijumpai penerapannya dalam masyarakat, sedangkan, di beberapa daerah lain seperti Jembrana, Klungkung, dan Bangli masih menolak bentuk perkawinan nyentana (nyeburin) yang secara proses menyerupai perkawinan matriarki, namun menurut esensinya status putrika pada anak perempuan yang menjadi sentana rajeg sudah didaulat berdasarkan pauman krama sebagai purusa (status laki-laki) penerus keturunan keluarga. Beberapa daerah lain seperti Karangasem, dan Kodya Denpasar, di satu sisi pada umumnya masyarakat menganut bentuk perkawinan patriarki, tapi dalam prakteknya tidak dapat dipungkiri ada beberapa desa seperti Tianyar, dan Abang di wilayah kabupaten Karangasem yang dijumpai telah melaksanakan bentuk perkawinan matriarki. Dikaitkan dengan pewarisan, pengaruh bentuk perkawinan matriarki terhadap anak perempuan yang semula bukan sebagai ahli waris dapat menjadi ahli waris terhadap harta orang tuanya. Implikasinya putrika mempunyai kewenangan yang sama dengan laki-laki untuk mewarisi harta kekayaan dan sanggah (tempat suci keluarga) sebagaimana layaknya laki-laki. Model rekonstruksi kebijakan perkawinan yang direkomendasikan oleh peneliti menjawab permasalahan di lapangan adalah penerapan model formulasi kebijakan perkawinan parental (Pada Gelahang).
\end{abstract}

Kata Kunci: perkawinan, matriarki, gender.

\begin{abstract}
In general, this study aims to develop a model of marriage laws gender-oriented village-based traditional Hindu Bali. This study will be conducted over three years, from 2015 until 2016. The output of the study for three years can be described as follows: (1) outputs the first year (2015) is composed of scientific articles in accredited journals and textbooks draft law of inheritance the influence
\end{abstract}


of gender-oriented marriage of traditional village-based Hindu Bali. (2) The outcome of the second year (2016) is composed of scientific articles in accredited national journals, and textbooks related to inheritance laws the influence of gender-oriented marital village-based traditional Balinese Hindu and scientific articles in international journals.

The results of the study form of marriage matriarki in some areas in the province of Bali as Buleleng, Tabanan, Gianyar, has found its application in society, whereas, in some other areas such as Jembrana, Klungkung and Bangli still refuse forms of marriage nyentana (nyeburin) which process resembles marriage matriarki, but according to its essence putrika status in young women who become Rajeg cemetery has been asked by pauman manners as purusa (status male) successor to the family lineage. Several other areas such as Karangasem, and Denpasar municipality, on the one hand to the general public embrace patriarchal forms of marriage, but in practice there is no doubt there are some villages like Tianyar, and brother in the district of Karangasem who are found to carry out the marriage form matriarki. Associated with inheritance, marriage forms matriarki effect against girls which was originally not as heirs may be heir to the wealth of their parents. , The implication putrika have the same authority as men to inherit wealth and corrected (sanctum family) as befits a man. Model reconstruction marriage policy recommended by researchers to answer the problem in the field is the application of the model policy formulation parental marriage (In Gelahang).

Keywords: marriage, matriarki, gender.

\section{PENDAHULUAN}

Perkawinan merupakan ikatan lahir batin antara seorang pria dengan seorang wanita sebagai suami istri dengan tujuan membentuk keluarga (rumah tangga) yang bahagia dan kekal berdasarkan Ketuhanan Yang Maha Esa (UU No. 1 Tahun 1974). Sedangkan pengertian perkawinan menurut Burgerljik Wet Boek (warisan Belanda) merupakan hubungan yang hanya bersifat perdata saja. Hal ini berarti bahwa perkawinan merupakan "kesepakaatan" atau "persetujuan" antara perseorangan yang tidak berkaitan dengan unsur religius-magis. Perkawinan dianggap sah dan legal apabila telah disepakati dan disetujui oleh masing-masing pihak serta dibukukan dalam bentuk akta perkawinan pada pada kantor catatan sipil.
Bagi masyarakat Hindu Bali perkawinan merupakan hubungan yang bersifat sakral dan suci antara pria dengan wanita dalam menjalankan dharma bahktinya sebagai manusia yang utuh. Ini berarti bahwa, secara ideal perkawinan akan dianggap sah dan legal secara hukum dan adat apabila disetujui oleh kedua mempelai, direstui dan disaksikan oleh keluarga kedua belah pihak, serta disaksikan secara niskala serta dilaksanakan melalui prosesi upacara adat. Hubungan yang bersifat sakral dan suci ini mesti dilandasi oleh rasa cinta untuk mewujudkan swadarmaning manusa lan swadarmaning pianak (kewajiban manusia untuk meneruskan kehidupan dan kewajiban seorang anak) (Surupa, 2002). Bagi seorang anak yang tidak mampu melanjutkan keturunan keluarga dan menjalankan kewajiban, diyakini

Jurnal IImu Sosial dan Humaniora $\mid 755$ 
orang tuanya tidak akan mendapatkan tempat yang baik ketika meninggal. Kondisi ini menyebabkan perkawinan, selain bermakna sebagai Sebuah hak sekaligus sebagai sebuah kewajiban yang harus dijalankan seorang anak dalam menersukan keturunan. Namun, dalam kenyataannya, tidak semua anak mampu melaksanakan kewajibannya sebagai seorang anak yang berkewajiban untuk meneruskan keturunan, yang disebabkan karena hukum perkawinan patriarhi yang mengharuskan hanya seorang anak laki-laki yang boleh menjadi penerus keturunan dan ahli waris keluarga. Anak perempuan hanya mempunyai hak atas harta kekayaan keluarga selama mereka masih muda saja. Ketika mereka sudah mulai bersuami secara otomatis tidak mempunyai hak untuk menikmati dan memperoleh warisan dari keluarganya, kecuali atas dasar kesukarelaan keluarganya (Metra, 2003).

Bagi keluarga yang tidak mempunyai keturunan laki-laki pada masyarakat patrilinial, merupakan akhir cerita dari keluarga mereka, karena akan diteruskan oleh ahkli waris dari keturunan kelurga lain yang masih memiliki hubungan darah. Hal ini menyebabkan banyak keluarga, yang harus diteruskan oleh keluarga lain yang bukan keturunan langsung, karena hanya mempunyai anak perempuan. Artinya keluarga yang tidak mempunyai keturunan laki-laki, berdasarkan hukum perkawinan patriarhi harus diwarisi dan diteruskan oleh keluarga lain yang masih mempunyai hubungan darah lurus ke-bawah atau lurus ke-samping (Jayanegara, 2005).Oleh karena itu, anak laki-laki bagi masyarakat patrilinial merupakan pelita dalam keluarga yang akan memberikan cahanya bagi orang tua dan masa depan keluarganya. Hal inilah yang menyebabkan keluarga patrilinial tidak akan berhenti "membuat anak" jika belum dikarunia pelita hati laki-laki sebagai penerus treh keluarga. Oleh karena itu, sering timbul selorohan "belum mejadi laki-laki kalau belum mempunyai anak laki-laki” yang disepadankan dengan "bancl", yang artinya bahwa keperkasaan seorang laki-laki dinilai dan diukur berdasarkan kemampunnya untuk "membuat" anak laki-laki. Kondisi dan asumsi sebagaimana telah tergambar di atas memang merupakan realita hidup yang tumbuh dan berkembang pada masyarakat Bali sampai saat ini, walapun secara ekonomis dan sosial budaya masyarakat Bali sudah banyak mendapatkan pengaruh dari masyarakat luar. Namun, dasar filosofi patrilinial telah tergurat dalam urat nadi masyarakat Bali dan senatiasa mewarnai budaya dan adat istiadatnya. Namun, perubahan dan kemajuan zaman serta semakin lewesnya hukum adat yang berlaku pada masyarakat Hindu Bali mengikis pola dan tradisi patrilineal yang dianut oleh masyarakat Hindu sehingga apa yang disampaikan Fukuyama, (2010 : 97) yang mengatakan bahwa tidak ada yang kekal di dunia ini selain perubahan, merupakan realitas sosial emprik yang terjadi pada masyarakat Hindu Bali. Senada dengan Sanjaya, (2008: iii) yang mengatakan peningkatan pemahaman dan pengetahuan masyarakat tentang hukum perkawinan dan kesetaraan akan hak dan kewajiban menyebabkan banyak keluarga yang hanya 
mempunyai keturunan perempuan, menjadikan anaknya sebagai ahli waris dan penerus keturunan. Bila sebelumnya terpola, bahwa hanya kaum pria yang boleh mewarisi keluarga dan meneruskan keturunan, tetapi dalam kondisi yang tidak memungkinkan karena keluarga hanya memiliki anak perempuan, maka anak perempuan bisa dijadikan sebagai ahli waris dan penerus keturunan (nyentana) yang nantinya akan menetap di rumah dengan status dan kedudukan sebagai purusa dan suami yang dipinangnya nanti akan diajak ke rumah si wanita. Dalam prakteknya, model perkawinan yang bersifat matriarhi ini mendapatkan berbagai perlawanan dan pertentangan di kalangan masyarakat Hindu Bali sendiri. Ada beberapa permasalahan yang terjadi akibat perkawinan matriarhi ini, yaitu; (1) belum adanya legitimasi secara hukum (awig-awig) tentang perkawinan matriarhi, walapun sudah banyak masyarakat yang melakukan perkawinan matriarhi, (2) pola kekerabatan patriarhi yang dianut oleh masyarakat Hindu Bali, (3) pola kekerabatan patriarhi yang berlaku pada masyarakat Hindu Bali sangat kental, dan (4) pola pikir, nilai-nilai dan tata laku kaum laki-laki yang sudah terbiasa dengan tradisi patriarhi menyulitkan kaum laki-laki untuk melakukan adaptasi pada rumah keluarga perempuan.

Penelitian Suastika, (2010: 35) tentang putrika (matriarhi) pada Masyarakat Bali Aga di Kabupaten Bangli menemukan, seiring dengan semakin meningkatnya keluarga di Kabupaten Bangli yang melakukan putrika bagi anak perempuannya, berbagai persoalan muncul dalam keluarga putrika. Kaum pria yang beristrikan putrika dan ikut bersama dengan keluarga sang istri ditengahtengah ideologi patilinial yang dianut masyarakat Bali menyadari kedudukan dan statusnya sebagai perempuan yang diperlakukan lanyaknya perempuan. Mereka merasa tertekan dan diperlakukan tidak sesuai dengan "kodratnya" sebagai kaum laki-laki. Di sisi lain, kaum pria yang pada masyarakat Bali yang dikenal dengan penyabung ayam "penjudi" dan kaum yang dikenal dengan tindakannya berpoya-poya, membuat kaum pria yang nyeburin semakin merasakan kehilangan "kelaki-lakiannya". Jika mereka bercerai dengan sang istri yang notabenenya telah menjadi putrika, maka sang suami tidak akan mendapatkan apapun, sehingga ada slogan dikalangan masyarakat setempat "binpidan cai mulih apa kar aban cai sejabin butuh" (nanti kalau kamu bercerai apa yang akan kamu bawa pulang kecuali alat kelamin). Persepsi seperti itu memang bukan isapan jempol semata, karena terbukti telah bayak percerain yang terjadi dalam rumah tangga putrika, dan sang suami pulang kerumah asal tidak membawa harta kekayaan sepeser pun. Demikian juga untuk perempuan putrika yang telah bercerai, status dan kedudukannya dalam keluarga menjadi tidak menentu karena sudah digantikan oleh sang anak (Windia, 2008).

Kenyataan seperti ini, juga terjadi pada masyarakat Bali pada umumnya, yaitu telah banyak terjadi perceraian pada keluarga nyentana, yaitu sang suami tidak mendapatkan hak dan kedudukan yang semestinya. Kajian harian umum Nusa Bali (5 Februari, 2010) tentang nyentana 
(matriarhi) menguraikan tentang berbagai persoalan keluarga nyentana, yang berkaitan dengan legalitas hukum adat dan legitimasi sosial pola dan sistem patrilinial yang dianut oleh masyarakat Bali. Wiayana, (2003; 3) mengatakan, perkawinan yang mengadopsi pola materilinial merupakan paradigma yang terbalik dari ideologi patrilinial yang sedemikian kuat dianut masyarakat Bali pada umumnya. Hal ini akan berimplikasi pada keberterimaan sosial masyarakat dan legalitas adat yang dipertanyakan. Senada dengan kajian Harian Umum Nusa edisi 04 Februari 2011, yang dalam salah satu kolomnya menyoroti tentang perkawinan nyentana di daerah Kabupaten Tabanan, mengatakan bahwa perkawinan matrilinial pada masyarakat patrilinial jika tidak dilakukan dengan orang yang masih mempunyai hubungan darah akan rawan terhadap perceraian dan keruntuhan rumah tangga. Fakta dan data ini tentunya akan sangat menyulitkan bagi kaum perempuan di Bali, karena di satu sisi mereka mempunyai tangung jawab untuk menerukan keterunan keluarganya dari keputungan (lenyap) dan di sisi lain dihadapkan pada kehancuran rumah tangga mereka yang berimplikasi pada status, kedudukan dan kewajiban mereka (Windia, 2008).

Beranjak dari proposisi di atas, tampak bahwa masyarakat Hindu Bali sedang mengalami masalah, karena di satu sisi setiap keluarga harus mempunyai ahli waris dan penerus keturunan keluarga, tetapi di sisi lain belum ada awig-awig desa adat yang berlaku secara umum pada masyarakat Hindu Bali yang mengatur perkawinan matriarhi. Kondisi ini, menjadikan perkawinan matriarhi mengalami berbagai permasalahan, yang berkaitan dengan legalitas formalnya, secara adat dan hukum. Bahkan di beberapa daerah, seperti Singaraja model perkawinan patriarhi ini tidak dikenal atau diistilahkan dengan perkawinan paid bangkung (dikendalikan perempuan). Karena itu, sangat urgen untuk dilakukan kajian secara mendalam dan komperhensif mengenai landasan hukum perkawinan patriarhi yang bertalian dengan pengungkapan tatanan kenyataan ideasional yang mencakup pengetahuan, nilai, norma, tradisi, kepercayaan, motif maupun alasan maknawi yang mendorong terjadinya perlawanan terhadap hukum perkawinan yang bersifat patriarhi, pengetahuan dan pemahaman perempuan dan masyarakat atas hak dan kewajiban perempuan, yang terdapat dalam UU, awig-awig, lontar, adat dan tradisi yang memungkinkan terjadinya hukum perkawinan berorientasi gender berbasis desa adat Hindu Bali. Fakta dan phenomena ini sangat menari untuk dikaji, sehingga dapat dilakukan rekonstruksi hukum perkawinan yang berorientasi gender dan tetap berpegang teguh pada eksistensi dan keutuhan desa adat. Permasalahan pokok ini dapat dirinci menjadi beberapa permasalahan penelitian, yaitu : (1) Bagaimanakah bentuk perkawinan matriarkhi yang dilakukan masyarakat Hindu Bali?, (2) Apakah tujuan pelaksanaan perkawinan matriarhi dan pengaruhnya terhadap kaum perempuan Bali?, Bagaimanakah tingkat keberterimaan masyarakat desa adat Hindu Bali terhadap perkawinan matriarhi, (4) Seperti Apakah bentuk formulasi hukum

Jurnal IImu Sosial dan Humaniora |758 
perkawinan berorientasi gender berbasis desa adat pada masyarakat Hindu Bali?

\section{METODE}

ini Secara metodologis, $\begin{gathered}\text { penelitian } \\ \text { merupakan }\end{gathered}$ pengembangan dalam bangunan rekayasa kebijakan publik (development research in public polecy paradigm) (Borg \& Gall, 1989), sehingga penekanannya bukan pada pengukuran, melainkan pada upaya pemetaan, sinkritasi, dan rekayasa secara aktual, faktual, dan holistik, emik, dan etik tentang bentuk dan makna perilaku yang ditampilkan oleh masyarakat desa adat dalam konteks latar belakang perkawinan matrilinial, prosesi perkawinan matrilinial, keberterimaan sosial masyarakat terhadap perkawinan matrilinial, konflik desa adat yang diakibatkan oleh perkawinan matrilinial, dan pengembangan model rekonstruksi hukum perkawinan berorientasi gender berbasis desa adat Hindu Bali untuk pembangunan dan peningkatan integritas desa adat sebagai simbolisme masyarakat Hindu Bali.

Upaya penggalian, analisis, dan pemetaan fokus masalah penelitian dilakukan dengan mengacu pada model analisis lintas-situs sebagaimana yang lazim dilakukan dalam penelitianpenelitian sosial dan budaya (Carspecken, 1998). Model analisis lintas-situs ini akan memudahkan peneliti dalam mengungkap dan memetakan masalah, kaitan masalah satu dengan masalah lainnya, dan kaitan masalah penelitian dengan latar alamiah penelitian sebagai faktor eksternal dalam analisis data penelitian. Berdasarkan pola analisis ini, akan dapat diformulasikan dan sekaligus diverifikasi bangunan informasi, metode, dan model baru dalam menghampiri masalah-masalah sejenis dengan tingkat kebenaran ilmiah yang lebih tinggi.

Secara skematis terkait dengan penghampiran dan telaah terhadap fokus masalah penelitian, berikut akan disajikan hal-hal yang telah dilakukan dan akan dilakukan melalui penelitian ini serta produk akhir pada setiap tahapannya, yaitu:

Penelitian ini akan dilakukan di 8 Kabupaten dan 1 Kota Madya di Provinsi Bali. Pemilihan lokasi ini didasari oleh beberapa rasional, yaitu: (1) masyarakat yang melakukan perkawinan matrilinial terdapat di semua kabupaten/kodya yang ada di Provinsi Bali, padahal masyarakat Hindu Bali menganut sistem kekerabatan dan pewarisan yang bersifat patrilinial, (2) hampir di seluruh kabupaten/kodya pernah terjadi konflik adat yang disulut oleh permasalahan perkawinan matrilinial, (3) sampai saat ini hampir disemua kabupaten/kodya yang ada di Provinsi Bali belum melegitimasi secara yuridis formal perkawinan matrilinial, sehingga sering menjadi pemicu terjadinya konflik pewarisan dan konflik penerusan keturunan serta konflik adat. Berdasarkan rasional di atas, maka penelitian ini dilihat dari lokasi pelaksanaannya melibakan semua Kabupaten/Kodya yang ada di Provinsi Bali.

Penelitian ini merupakan penelitian pengembangan, yaitu ada pembalikan cara berpikir masyarakat tentang perempuan berhak mewaris. Langkah pengembangannya adalah ada perubahan cara pandang masyarakat 
Bali tentang gender dalam hukum bahwa perempuan Bali diberikan hak mewaris dengan penyelenggaraan bentuk perkawinan nyentana yang dalam proses selaras dengan bentuk perkawinan matriarki dan dalam substansi dikukuhkannya sentana rajeg, yaitu anak perempuan yang dalam suatu keluarga ditunjuk sebagai penerus keturunan dan ahli waris yuang dalam hal ini berstatus sebagai purusa (patriarki).

Responden/informan dalam penelitian ini akan ditentukan dengan menggunakan teknik sampling bertujuan (purposive sampling) dan jumlah responden akan dikembangkan secara alamiah sesuai dengan kebutuhan data penelitian dengan menggunakan prinsip Snowball Sampling. Berdasarkan rasional pengambilan sampel/responden penelitian di atas, maka responden dalam penelitian ini terdiri dari beberapa kelompok responden, yaitu: pasangan suami istri yang melakukan perkawinan matrilinial, (2), orang tua dan keluarga pasangan suami istri yang melakukan perkawinan matrilinial, (3), tokoh agama dan tafsir weda (kitab suci agama Hindu), (4) tokoh adat (orang yang dituakan di setiap desa adat), (5) tokoh masyarakat formal (anggota legislatif, eksekutif, dan tokoh pemerintahan daerah lainnya), (6) tokoh pemuda, (7) anggota masyarakat, (8) PHDI (organisasi tertinggi agama Hindu) provinsi Bali. Secara diagramatik, proses analisis data yang akan dilakukan dapat dijabarkan sebagai berikut:

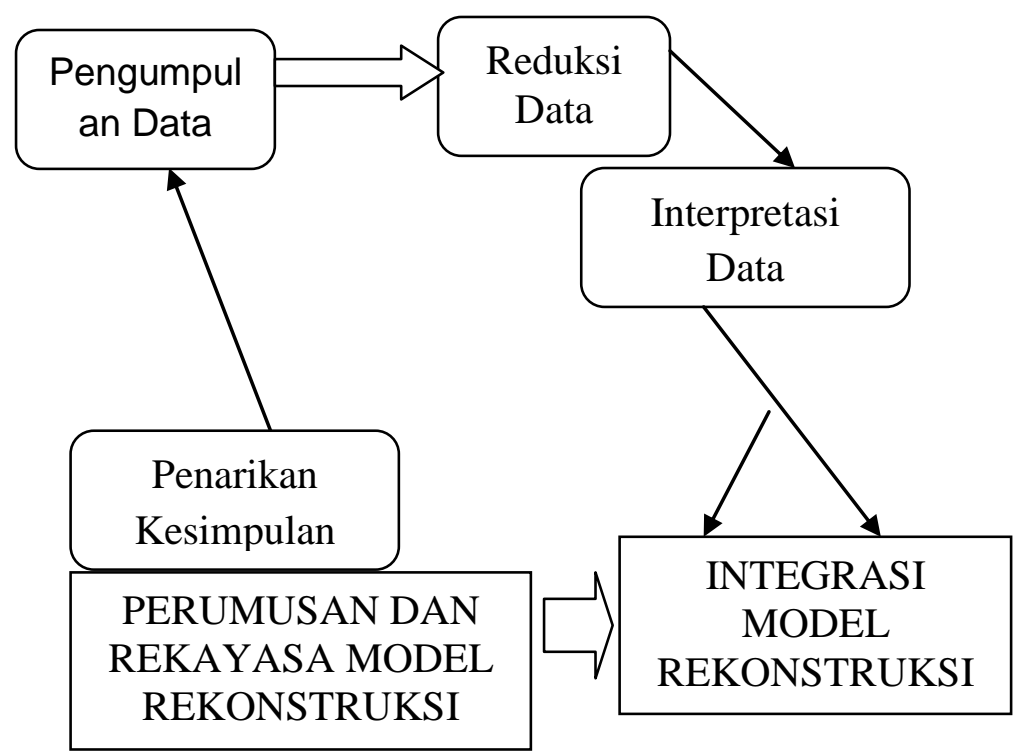

Penelitian ini menganut prinsip "human instrument", yaitu peneliti merupakan metode pengumpulan data yang utama. Hal ini penting mengingat fokus masalah penelitian benar-benar memerlukan mempertaruhkan kapabilitas personal peneliti, sehingga mampu mengungkap bebagai aspek yang terkait dengan fokus masalah dan kebutuhan data penelitian. Dalam pelaksanaannya, peneliti mengunakan beberapa alat 
bantu pengumpulan data, yaitu: (1) wawancara mendalam, (2) observasi partisipatif, (3) pencatatan dokumen, (4) kuisioner terbuka dan tertutup, (5) focus groups discussion, (6) expert judgement, dan (7) handy camp untuk merekam proses perkawinan matrilinial yang dilakukan oleh pasangan pengantin. Data yang terkumpul dalam penelitian ini berupa data kualitatif dan data kuantitatif. Keseluruhan data ini dianalisis dengan menggunakan teknik analisis deskriptif dan statistik sesuai dengan karakteristik data yang dibutuhkan untuk mengurai masingmasing permasalahan penelitian. Miles dan Huberman (1992: 83), mengemukakan bahwa aktivitas dalam analisis data kualitatif dilakukan secara interaktif dan berlangsung secara terus menerus sampai tuntas, sehingga datanya sudah jenuh.

\section{HASIL DAN PEMBAHASAN \\ Bentuk Perkawinan Matriarki pada Masyarakat Hindu Bali}

Perkawinan ialah ikatan sekala niskala (lahir batin) antara seorang pria dengan seorang wanita sebagai suami istri dengan tujuan membentuk keluarga yang bahagia dan kekal (satya alaki rabi). Dharmasampati yang berarti bahwa pernikahan merupakan salah satu dharma yang harus dilaksanakan sebagai umat Hindu sesuai dengan ajaran Catur Ashrama, sehingga pasangan suami istri melaksanakan: Dharmasastra, Artasastra, dan Kamasastra. Jika dikaitkan dengan Catur Purusaarta, maka pada masa Grhasta manusia Hindu telah melaksanakan Tripurusa, yaitu Dharma, Artha, dan Kama. Purusa keempat (Moksa) akan sempurna dilaksanakan bila telah melampaui masa Grhasta yaitu Wanaprasta dan Saniyasin. Melalui pernikahan ini juga kedua mempelai diberikan jalan untuk dapat melaksanakan dharma secara utuh seperti dharma seorang suami atau istri, dharma sebagai orang tua, dharma seorang menantu, dharma sebagai ipar, dharma sebagai anggota masyarakat sosial, dharma sebagai umat, dan sebagainya.

Matriarki (nyentana) adalah hukum adat, bukan kaidah agama Hindu. Mungkin ada sedikit kaitan dengan tradisi beragama Hindu di Bali, di mana dikenal adanya istilah "Pradana" dan "Purusha". Seseorang yang nyentana hendaknya mendapat persetujuan dahulu dari segenap krama dadia (soroh) dari lelaki dan perempuan, karena yang lelaki akan melepaskan hak/kewajibannya di sanggah lama (purusha) dan menjadi warga baru di sanggah baru (pradana). Lelaki yang nyentana biasanya menyembah dua kawitan yaitu kawitannya yang lama dan kawitan istrinya. Bahwa perkawinan itu bisa saja berlangsung dengan bahagia, bergantung dari bagaimana si suamiistri bisa menciptakan surga dalam kehidupan rumah tangganya. Istilah yang kurang enak itu hanyalah ungkapan dari sifat-sifat arogansi superioritas kaum lelaki

Dalam masyarakat adat di Bali, status hukum suami-istri serta anakanak dalam keluarga sangat ditentukan oleh bentuk perkawinanmya. Apakah suami-istri itu dan anak-anaknya berkedudukan hukum di keluarga pihak suami ataukah di keluarga pihak istri sangat dipengaruhi oleh bentuk perkawinan yang dipilih. Undangundang perkawinan tidak mengatur 
mengenai bentuk-bentuk perkawinan ini. Namun, persoalan mengenai bentukbentuk perkawinan ini sama sekali tidak dapat diabaikan dalam keseluruhan sistem perkawinan yang berlaku bagi umat Hindu di Bali. Status atau kedudukan hukum seseorang di dalam keluarga sangat penting artinya dalam hukum adat Bali karena akan mempengaruhi hak (swadikara) dan kewajiban (swadharma) orang tersebut dalam keluarga dan masyarakat (banjar/desa pakraman). Swadharma dan swadikara dalam keluarga misalnya menyangkut tanggungjawab pemeliharaan terhadap anak atau pemeliharaan terhadap orang tua di masa tuanya, hak dan kewajiban terhadap harta warisan, tanggung jawab terhadap pemeliharaan dan kelangsungan serta pemujaan terhadap tempat persembahyangan keluarga (sanggah/merajan) di mana roh leluhur disemayamkan, dan lain-lain. Tanggung jawab kemasyarakatan menyangkut tanggung jawab sebagai anggota kesatuan masyarakat hukum adat (banjar/desa pakraman, subak, dadia), baik dalam bentuk ayahan (kewajiban kerja), pawedalan/papeson (urunan berupa uang atau barang), dan lain-lain.

Pada masa lalu, dalam masyarakat adat di Bali dikenal beberapa bentuk perkawinan. Sebagian dari bentuk-bentuk perkawinan tersebut sudah lama ditinggalkan oleh masyarakat karena sudah tidak sesuai lagi dengan perkembangan zaman. Bentuk perkawinan yang dulu ada tetapi kini sudah ditinggalkan adalah bentuk perkawinan matunggu atau nunggonin dan bentuk perkawinan paselang (Windia,dkk, 2009). Berikut ini akan dijelaskan bentuk-bentuk perkawinan yang masih lazim dilakukan dalam masyarakat umat Hindu di Bali serta bentuk perkawinan baru yang tumbuh dan berkembang seiring dengan perkembangan masyarakat.

Di luar bentuk perkawinan yang umum tersebut, dibeberapa daerah di Bali, terutama Tabanan, Badung, Gianyar, dan Bangli sudah lazim pula ditemui bentuk perkawinan yang sekarang lazim disebut nyeburin. Di beberapa tempat bentuk perkawinan ini lebih dikenal dengan sebutan nyentana atau nyaluk sentana (Korn,1978). Dalam bentuk perkawinan ini justru suamilah yang mengikuti istri. Secara sepintas, bentuk perkawinan ini tampak menyimpang dari sistem kepurusa yang menekankan bahwa keturunan dilanjutkan oleh keturunan laki-laki (purusa). Akan tetapi, bila diamati secara seksama, perkawinan nyeburin ternyata tetap konsisten dengan sistem kekeluargaan kepurusa sebab dalam perkawinan ini status istri adalah purusa karena telah ditetapkan sebagai sentana rajeg dalam keluarganya.

Sentana rajeg (sentana = keturunan, ahli waris; rajeg= kukuh, tegak; karajegang= dikukuhkan, ditegakkan) adalah anak perempuan yang kerajegang sentana yaitu dikukuhkan statusnya menjadi penerus keturunan atau purusa. Dalam Kitab Manawa Dharmacastra (IX:127), sentana rajeg disebut dengan istilah putrika yang kedudukannya sama dengan anak lakilaki, yaitu sebagai pelanjut keturunan dan ahli waris terhadap harta orang tuanya (Sudantra,2002).

Dalam bentuk perkawinan ini, suami yang berstatus sebagai pradana dilepaskan hubungan hukumnya dengan keluarga asalnya selanjutnya masuk

Jurnal IImu Sosial dan Humaniora |762 
dalam keluarga kepurusa istrinya. Dengan demikian, keturunan dalam keluarga kepurusa itu tetap dilanjutkan oleh anak yang berstatus purusa. Anak yang lahir dari perkawinan ini berkedudukan hukum dalam keluarga ibunya, sehingga menunaikan kewajiban (swadharma) dan mendapatkan haknya (swadikara) dalam keluarga ibu.

Ciri yang menunjukkan bahwa bentuk perkawinan tersebut adalah nyeburin bukanlah semata-mata karena suami (umumnya) tinggal di rumah keluarga istri, melainkan lebih dapat dilihat dari fakta bahwa upacara pengesahan perkawinan (pasakapari) dilaksanakan di rumah keluarga mempelai perempuan dan keluarga mempelai perempuanlah yang mengantarkan sajen-sajen pemelepehan (jauman) ke rumah keluarga mempelai laki-laki sebagai sarana untuk melepaskan hubungan hukum mempelai laki-laki terhadap keluarga asalnya (Panetja,1986).

Perkawinan matriarki (nyentana) menurut Kaler (1982) adalah nama suatu jenis atau bentuk perkawinan menurut adat agama Hindu di Bali, dalam mana sang perempuan ditetapkannya kedudukan selaku purusa (laki-laki). Suatu perkawinan untuk dapat disebut perkawinan nyentana haruslah mengikuti kaidah-kaidah menurut hukum adat Bali sebagai berikut :

(1) Pihak perempuan harus berstatus sentana rajeg, artinya perempuan yang akan menikah harus ditetapkan sebagai penerus keturunan.

(2) Perundingan untuk melakukan perkawinan nyentana harus dimulai dari pihak orang tua calon istri dengan keluarga calon suami. Tentu saja pendekatan itu yang utama terhadap sang calon suami yang bersangkutan. Bila telah ada kesepakatan barulah perkawinan nyentana dilaksanakan. Biasanya proses inilah yang paling sulit, karena sering terjadi anaknya sudah memberikan persetujuan sedangkan keluarga orang tuanya menolak

(3) Upacara perkawinan yang paling pokok dan merupakan syarat sahnya perkawinan, yaitu upacara mebyakaon, harus dilakukan di rumah si istri.

(4) Pihak suami harus masuk pihak istri dan diterima sebagai anggota keluarga pihak istri. Ini artinya pihak suami keluar dari rumpun keluarga asalnya, yang secara kongkrit ditunjukkan si suami semula sudah tinggal di rumah istrinya. Suami tidak lagi memuja sanggah atau merajan (tempat sembahyang) bapak asalnya, melainkan ia harus memuliakan sanggah atau merajan pihak istri. Sebagai bentuk kesungguhan dan legalitas religiusnya calon suami melakukan upacara mepamit di sanggah asal.

(5) suami berkedudukan sebagai sentana nyeburin, yaitu mempunyai hak sebagai predana (wanita) dan ini ditunjukkan dengan adanya pihak istri mengantar sajen-sajen pamelepehan (jauman) ke rumah keluarga si laki-laki sebagai upacara pelapasan ikatan si suami dari keluarga asalnya sebagai purusa (Panetja, 1989).

Bentuk perkawinan matriarki di beberapa daerah di propinsi Bali seperti Buleleng, Tabanan, Gianyar, telah dijumpai penerapannya dalam 
masyarakat. Di beberapa daerah lain seperti Jembrana, Klungkung, dan Bangli masih menolak bentuk perkawinan tersebut karena sistem perkawinan yang dianut oleh sebagian besar masyarakatnya adalah sistem perkawinan patriarki. Beberapa daerah lain, seperti Karangasem, dan Kodya Denpasar, di satu sisi pada umumnya masyarakat menganut bentuk perkawinan patriarki, tetapi dalam prakteknya tidak dapat dipungkiri ada beberapa desa seperti Tianyar, dan Abang di wilayah kabupaten Karangasem yang dijumpai telah melaksanakan bentuk perkawinan matriarki. Hanya saja keabsahannya dari segi naungan oleh prajuru adat belum jelas sehingga di kemudian hari apa ada perselisihan di dalam keluarga perihal status anak dan prihal warisan belum diketahui mekanisme penyelesaiannya.

\section{Tujuan Pelaksanaan Perkawinan Matriarhi dan Pengaruhnya terhadap Kaum Perempuan Bali}

Adapun 3 tujuan pernikahan menurut ajaran Hindu menurut kitab Kitab Manavadharmasastra yaitu:

(1) Dharmasampati, kedua mempelai secara bersama-sama melaksanakan dharma yang meliputi semua aktivitas dan kewajiban agama seperti melaksanakan Yajña, sebab di dalam grhastalah aktivitas Yajña dapat dilaksanakan secara sempurna.

(2) Praja, kedua mempelai mampu melahirkan keturunan yang akan melanjutkan amanat dan kewajiban kepada leluhur. Melalui Yajña dan lahirnya putra yang suputra seorang anak akan dapat melunasi hutang jasa kepada leluhur (Pitra rna), kepada Deva (Deva rna) dan kepada para guru (Rsi rna).

(3) Rati, kedua mempelai dapat menikmati kepuasan seksual dan kepuasan-kepuasan lainnya (Artha dan kama) yang tidak bertentangan dan berlandaskan Dharma.

Tujuan lain dari pernikahan menurut ajaran Hindu adalah membentuk keluarga ( rumah tangga) yang bahagia dan kekal maka dalam agama Hindu sebagaimana diutarakan dalam kitab suci Veda perkawinan adalah terbentuknya sebuah keluarga yang berlangsung sekali dalam hidup manusia.

Beberapa orang menganggap bahwa bentuk perkawinan matrilokal (nyeburin) ini sebagai penghargaan terhadap perempuan Bali karena dengan diangkat statusnya sebagai sentana rajeg, perempuan yang kawin kaceburin sekaligus menjadi ahli waris dari harta orang tuanya. Dikaitkan dengan pewarisan, barangkali pandangan tersebut ada benarnya karena anak perempuan yang semula bukan sebagai ahli waris dapat menjadi ahli waris terhadap harta orang tuanya. Akan tetapi, dalam kasus tertentu, sesungguhnya pandangan tersebut tidak sepenuhnya benar, terutama jika dikaitkan dengan kebebasan anak perempuan dalam memilih jodoh. Akibat dari tangung jawabnya yang akan ditetapkan sebagai sentana rajeg yang harus "tinggal di rumah" ia harus berhati-hati jatuh cinta pada laki-laki, karena ia mesti menyelidiki dan memastikan terlebih dahulu bahwa lakilaki yang mendekatinya mau nyentana. Di zaman di mana banyak keluarga 
melaksanakan keluarga berencana dengan semboyan "dua anak cukup, laki-perempuan sama saja", tentu saja cukup sulit menemukan laki-laki yang besedia nyentana. Dengan demikian, perempuan itu bisa "terpenjara" dengan statusnya sebagai sentana rajeg.

\section{Tingkat Keberterimaan Masyarakat Desa Adat Hindu Bali terhadap Perkawinan Matriarki}

Bentuk perkawinan matriarki (nyentana) atau nyeburin yang mulamula berkembang pada masyarakat Tabanan ini diterima secara luas oleh masyarakat Bali, khususnya Bali Selatan. Model kawin nyentana ini menjadi solusi yang mampu menyelesaikan persoalan keluarga yang hanya mempunyai keturunan perempuan. Dalam perkembangan selanjutnya perkawinan nyentana menjadi alternatif jika hanya mempunyai keturunan perempuan. Namun, persoalan yang menimpa keluarga yang hanya memiliki keturunan perempuan belum selesai sampai di sana. Sering terjadi persoalan berkaitan dengan pasangan pria yang akan diajak nyentana juga menjadi akhli waris dan penerus keturunan di dalam keluarganya atau sama-sama anak tunggal. Sebagai solusi terhadap kondisi tersebut, maka berkembanglah kemudia perkawinan pada gelahang atau perkawinan negen pada masyarakat Bali.

Pada masyarakat Bali dikenal beberapa kelompok kekerabatan yang dibedakan berdasarkan bentuknya. Kelompok kekerabatan pertama, disebut kuren yaitu ikatan suami istri yang terjadi akibat hubungan perkawinan. Satu kuren berarti sepasang suami istri termasuk anak-anaknya. Kuren berasal dari kata keren yang artinya "dapur", di samping itu dapat juga diartikan "rumah tangga". Orang-orang yang sudah membentuk rumah tangga disebut mekurenan (berkeluarga) (Majelis Pembina Lembaga Adat Daerah Tingkat 1 Bali 1989/1990). Orang yang telah berkeluarga berubah satus kehidupannya dalam masyarakat yaitu tidak lagi berstatus teruna atau daa (bujangan) melainkan adalah berstatus tua, atau dengan kata lain mereka digolongkan ke dalam golongan tua. Maka itulah perkawinan di Bali disebut nganten yang berasal dari kata ganti. Nganten berarti berganti status hidup, yaitu dari brahmacari (masa muda) ke grahasta (masa berumah tangga). Dengan demikian orang yang sudah berumah tangga akan terdaftar sebagai anggota atau krema banjar dan sekaligus menjadi anggota desa adat.

Pada umumnya kuren menetap secara virilokal, tetapi ada juga yang menetap secara neolokal. Virilokal adalah adat menetap suami, istri dan anak-anaknya yang tinggal di lingkungan rumah orang tua suami, sedangkan neolokal adalah menetap suami, istri dan anak-anaknya tidak tinggal di pekarangan rumah orang tua suami, tetapi mereka masih tetap merupakan satu kelompok kekerabatan. Hal ini terjadi terutama pada keluarga yang mempunyai anak laki-laki banyak, sedangkan tanah untuk perumahan atau tempat tinggal sempit. $\mathrm{Di}$ samping kedua adat menetap seperti tersebut di atas, ada juga adat di mana kuren menetap secara uxorilokal, yaitu laki-laki setelah kawin, hidup menetap di keluarga rumah keluarga istri atau 
sering juga disebut perkawinan nyentana/nyeburin (Suyatna, 1982).

Tempat kuren menetap dapat menentukan garis keturunan dan hak waris dari anak-anak serta keturunan mereka selanjutnya. Jika kuren menetap secara virilokal dan neolokal maka anak-anak mereka selanjutnya diperhitungkan secara purusa (patrilinial). Sebaliknya, keturunan dari kuren yang menetap secara uxorilokal diperhitungkan secara pradana (matrilinial) di mana anak-anak dan keturunanya disebut sentana dan ibunya disebut dengan putrika (Titib, 1998). Putrika diartikan anak perempuan yang "diubah" status dan kedudukannya secara adat menjadi anak laki-laki, sehingga bisa mengambil laki-laki untuk diajak ke rumah kerabat sang perempuan. Implikasinya putrika mempunyai kewenangan yang sama dengan laki-laki untuk mewarisi harta kekayaan dan sanggah (tempat suci keluarga) sebagaimana layaknya lakilaki.

Kelompok kekerabatan yang kedua, disebut pakurenan (keluarga luas) merupakan kuren-kuren yang menetap dan tinggal bersama dalam satu pekarangan, tetapi terpecah dalam beberapa keluarga inti, pada bangunan tersendiri dan mengatur ekonomi rumah tangga secara otonom. Biasanya pekarangan dilingkari tembok atau dinding dengan sebuah pintu untuk masuk dan keluar. Kelompok rumah seperti ini disebut dengan compound. Mordock dalam Lasmawan, (1999) menyebutkan bahwa keluarga luas atau extended family ini disebut dengan keluarga ambilinial kecil. Kelompok kekerabatan ini terjadi bila satu keluarga luas yang utrolokal, di mana merupakan kekerabatan yang terdiri atas keluarga inti baik keluarga inti dari anak laki-laki mapun keluarga inti dari anak perempuan. Kelompok kekerabatan yang ketiga disebut dengan klen, baik yang bentuknya kecil mapun besar. Kelen kecil disebut dadia adalah suatu kelompok kekerabatan patrilinial yang terdiri dari beberapa pakurenan dan berasal dari nenek moyang yang sama (Pitana, 1997). Anggota-anggota dalam satu dadia ikatan kekerabatannya sangat erat. Mereka masih mengetahui sil-silah kekerabatan, masih saling mengenal, dan saling bergaul walapun mereka pisah pekarangan. Umumnya sebagaian besar masih tinggal dalam satu desa. Hubungan kekerabatan ini ditandai dengan adanya tempat pemujaan leluhur yang disebut pura dadia.

\section{Bentuk Formulasi Hukum Perkawinan Berorientasi Gender Berbasis Desa Adat pada Masyarakat Hindu Bali}

Peran gender adalah peran yang dapat dilakukan oleh siapapun, baik lakilaki mapun perempuan termasuk dalam bidang pewarisan dan perkawinan, baik laki-laki maupun perempuan berhak untuk menjadi ahli waris dan meneruskan garis keturunan keluarga. Tampaknya kondisi equlibrium antara laki-laki dengan perempuan merupakan kulminasi yang akan menjadi tujuan setiap masyarakat termasuk masyarakat Bali. Kondisi ini ditandai dengan semakin luesnya hukum adat yang berlaku pada masyarakat Bali yang pada mulanya menganut idiologi patriarhi "tulen".

Rasional pemilihan desain dan model formulasi hukum perkawinan tersebut untuk menggali dan 
memformulasikan perkawinan matriarki bentuk penerapan dan pengaruhnya terhadap status dan kedudukan kaum perempuan pada masyarakat Desa Adat Bali yang perlu diperdalam lagi dalam penelitian ini adalah dibutuhkan data pendukung keberterimaan masyarakat Bali terhadap bentuk perkawinan matriarki menurut hukum adat, prosesi perkawinan, dan nilai sosial kultur yang tumbuh dan berkembang pada masyarakat Desa Adat Bali. Pertimbangan mendasar yang perlu diambil oleh peneliti sebelum memberikan rekomendasi terhadap model formulasi kebijakan perkawinan parental terhadap bentuk perkawinan yang selama ini ada. Langkah ini diambil mengingat di tengah masyarakat tumbuh dan berkembang bentuk perkawinan matriarki di tengah berlangsungnya bentuk perkawinan matriarki. Tingkat keberterimaan masyarakat di kabupaten Tabanan dan Gianyar terlihat jelas dengan dilangsungkannya secara turun temurun bentuk perkawinan matriarki. Namun, tanggapan lain justru datang dari daerah Bangli, Klungkung, dan Jembrana bahwa daerah tersebut tidak melazimkan bentuk perkawinan matriarkhi, bahkan kalaupun dalam keluarga tidak memiliki keturunan lakilaki, pihak keluarga dapat mengambil alternatif dengan menunjuk pihak keluarga sampingan dari garis keturunan purusa (laku-laki) untuk bertindak selaku ahli waris atau dengan jalan mengangkat anak dengan prosesi upacara adat. Di daerah kabupaten karangasem, kodya Denpasar, maupun Buleleng bentuk perkawinan matriarki dijumpai hanya saja masih bisa dihitung dengan jari. Dilangsungkannya bentuk perkawinan ini tidak diketahui secara jelas pihak siapa saja yang menyetujuinya karena aparatur desa adat maupun desa dinas hanya hadir sebagai saksi dan juru catat dalam pendaftaran perkawinan. Apabila terjadi konflik di kemudian hari status hukum dan pewarisan tidak diketahui secara pasti siapa pihak yang turut andil berkontribusi untuk membantu penyelesaiannya. Jaminan status hukumnya lemah karena masyarakat secara mayoritas masih menganut sistem perkawinan patriarki di daerah tersebut.

Oleh karena itu, menindak lanjuti permasalahan penelitian di atas, peneliti mengajukan rekomendasi untuk tetap menghormati kesetaraan gender di tengah berkembangnya sistem purusa di Bali, alternatif kebijakan yang tepat diusulkan adalah dengan penerapan model formulasi kebijakan perkawinan parental (Pada Gelahang). Perkawin pada gelahang ini merupakan sesuatu yang lazim berlaku pada masyarakat Desa Adat di Bali. Karena adanya perlakuan yang setara antara laki-laki dengan perempuan dalam bidang pewarisan dan penerusan keturunan. Rekomendasi peneliti atas dasar pertimbangan bahwa bentuk perkawinan matriarki tidak bisa sepenuhnya dilaksanakan di seluruh masyarakat Bali, karena di sisi lain masyarakat Bali juga kental dengan sistem pewarisan purusa, alternatif model formulasi ini diberikan untuk menciptakan equilibirium antara pihak purusa dan predana dalam hal melanjutkan keturunan dan pewarisan yang ditinjau dari berbagai bidang di antanya: dengan model formulasi perkawinan Pada Gelahang , mengenai status kepala 
keluarga pada catatan sipil akan lebih terjamin, status anak-anak yang dilahirkan, dan berkaitan dengan hukum adat yang "mengharuskan" mepamit/mejauman pada sanggah merajan sebagai tanda telah terputusnya hubungan kekeluargaan sehingga jelas dari kedudukan mempelai di dalam keluarga asal dan keluarga baru yang akan dibentuk. Di sisi lain, pengaruh pada keutuhan rumah tangga pasangan suami istri yang melakukan perkawinan pada gelahang lebih akan terjaga harmonisasi sebagaimana, dan apabila sewaktuwaktu terjadi perselisihan yang tidak bisa dijembatani melalui forum adat, permasalahan bisa diselesaikan melalui pengadilan negeri dengan mengambil langkah mediasi terlebih dahulu oleh kedua belah pihak.

\section{PENUTUP}

(1)Dalam bentuk perkawinan matriarki ini, suami yang berstatus sebagai pradana dilepaskan hubungan hukumnya dengan keluarga asalnya selanjutnya masuk dalam keluarga kepurusa istrinya. bentuk perkawinan matrilokal (nyeburin) ini sebagai penghargaan terhadap perempuan Bali karena dengan diangkat statusnya sebagai sentana rajeg, perempuan yang kawin kaceburin sekaligus menjadi ahli waris dari harta orang tuanya.

(2)Dikaitkan dengan pewarisan, barangkali pandangan tersebut ada benarnya karena anak perempuan yang semula bukan sebagai ahli waris dapat menjadi ahli waris terhadap harta orang tuanya. Putrika diartikan anak perempuan yang "diubah" status dan kedudukannya secara adat menjadi anak laki-laki, sehingga bisa mengambil laki-laki untuk diajak kerumah kerabat sang perempuan.

(3) Implikasinya putrika mempunyai kewenangan yang sama dengan lakilaki untuk mewarisi harta kekayaan dan sanggah (tempat suci keluarga) sebagaimana layaknya laki-laki. memformulasikan perkawinan matriarki bentuk penerapan dan pengaruhnya terhadap status dan kedudukan kaum perempuan pada masyarakat Desa Adat Bali. Di tengah bentuk perkawinan matriarki yang berkembang, pada kenyataannya masyarakat Bali masih menganut bentuk perkawinan patriarki. Dengan tanpa meniadakan salah satu diantara keduanya, di satu sisi masyarakat bali masih taat dengan sistem pewarisan purusa yang selama ini berlaku, dengan dinamika perubahan tatanan kehidupan masyarakat dan adanya wujud penghormatan terhadap pihak laki-laki terhadap perempuan dalam hukum adat agama Hindu.

(4)Peneliti memberikan rekomendasi dengan penerapan model formulasi bentuk perkawinan parental (Pada Gelahang) sebagai sebuah alternatif kebijakan di bidang perkawinan yang mempertimbangkan aspek keseimbangan perlakuan terhadap kedua belah pihak baik purusa (lakilaki) maupun predana (perempuan).

Jika bentuk perkawinan matriarki pada masyarakat Hindu Bali tidak dilandasi dasar hukum yang kuat akan menimbulkan berbagai persoalan yang berkaitan dengan status, kedudukan, dan tangung jawab masing-masing pihak. Oleh karena itu, peneliti 
menyarankan agar pihak desa Adat maupun pemerintah daerah dalam menetapkan kebijakan harus tetap memperhatikan kaidah hukum adat yang memperhatikan hak-hak perempuan Bali dalam kerangka kesetaraan gender.

\section{DAFTAR PUSTAKA:}

Borg and Gall. (1989). Educational Research: An Introduction. Fifth Edition. New York and London: Longman

Carspecken, P. (1998). Critical Etnography in Educational Research: A Theoritical an Practical Guide. London and New York: Routledge.

Jayanegara, P. (2005). Pokok-Pokok Hukum Perdata (Buku Pedoman Mahasiswa). Singaraja. IKIP Negeri Singaraja

Kaler. I. (1982) Butir-butir Tercecera tentang Adat Bali. Denpasar Bali Agung.

Lasmawan, W. (2002). Saih Nembelas sebagai Lembaga Desa Adat dalam Pemerintahan Desa Tradisional Bali. Laporan Penelitian. Singaraja: FKIP UNUD.

Metra, M. (2003). Perempuan dan Transformasi Sosial ekonomi Bali. Makalah. Disampaikan pada Pertemuan Ikatan Alumni IKIP Negeri Singaraja.

Miles dan Huberman. (1992). Analisis Data Kualitatif Buku Sumber Tentang Motode-Metode Baru. (Tjejep Rohendi Penerjemah). Jakarta : UI Press.

Panetje, G. (1989) Aneka Catatan Tentang Hukum Adat Bali : Denpasar: Guna Agung.
Purnawati, D. (2009). TRADISI POLIGAMI (Dasar Hukum dan Implikasinya Terhada Perempuan pada Masyarakat Desa Soangan). Laporan Penelitian. Singaraja : Universitas Pendidikan Ganesha.

Sanjaya, (2008). Perkawinan Nyentana (Studi Etnografi pada masyarakat di Kabupaten Tabanan Provinsi Bali). Laporan Penelitian. Singaraja. Universitas Pendidikan Ganesha.

Suastika. (2010) PUTRIKA (Studi Kasus Perubahan Status dan Kedudukan Perempuan pada Masyarakat Desa Bali Aga di Kabupaten Bangli). Laporan Penelitian. Singaraja: Universitas Pendidikan Ganesha.

Subekti. (1992). Kitab Undang-Undang Hukum Perdata. Bandung. Pradnya Paramita.

Suyatna, G. (1982). Ciri-ciri Kedinamisan Kelompok Sosial Tradisional dan Peranannya dalam Pembangunan. Disertasi. Bogor: Fak. Pertanian IPB Wiyana, K. (2003). Palinggih di Pamerajan. Denpasar: Upada Sastra.

Windia. (2008). Bias Gender: Perkawinan Terlarang Pada

Masarakat Bali. Denpasar: Udayana University Press. , (1997). Tanya Jawab Hukum Adat Bali. Denpasar: Upada Sastra 